\title{
Spina Iliaca Anterior Superior Avulsion Fracture: A Case Report and Review of the Literature
}

\section{Spina iliaka Anterior Superior Avülsiyon Kırığı: Olgu Sunumu ve Literatüre Genel Bakış}

\author{
(D) Mehmet Anil PULATKAN1, id Cemil Burak DEMIRKIRAN1, id Mustafa UZUN², id İbrahim TUNCAY¹
}

'Bezmiâlem Vakıf University Faculty of Medicine, Department of Orthopedics and Traumatology, İstanbul, Turkey

2Bezmiâlem Vakıf University Faculty of Medicine, İstanbul, Turkey

\begin{abstract}
Spina iliaca anterior superior (SIAS) avulsion fracture is a type of injury that is rare and possible to be overlooked in emergency services. SIAS is the insertion area of the Tensor fascia lata and Sartorius muscles, which are two of the hip flexor muscles and forceful contractions of these muscles which can be observed while kicking a ball, can lead avulsion fractures of SIAS, especially among adolescents. In our case, a 16-year-old male athlete attended the emergency service with a movement restriction and severe pain causing limping that started as an instant pain in the left hip after kicking the ball during a soccer game. It was misdiagnosed as soft tissue injury and no radiological imaging was performed. After plain radiography of the hip was performed in control appointment, the patient was diagnosed as having SIAS avulsion fracture, and a complete and pain-free range of motion was achieved after a conservative treatment of nonsteroid anti-inflammatory drugs, three weeks rest along with cold therapy and walking with crutches without full weight bearing. Even though SIAS fractures are generally treated with conservative methods, they can be misdiagnosed as soft tissue injury in case of poor physical examination and especially displaced fractures may cause clinical problems.
\end{abstract}

Keywords: Avulsion fracture, pelvis, apophysis, spina iliaca anterior superior

\section{ÖZ}

Spina iliaka anterior superior (SİAS) avülsiyon kırıkları nadir ve acil servis değerlendirmesinde gözden kaçabilecek yaralanmalardır. SİAS, kalça fleksör kaslarından olan tensor fasia lata ve sartorius kaslarının başlangıç bölgesidir. Özellikle adölesanlarda topa vurma esnasında bu kasların kuvvetli kontraksiyonlarıyla avülsiyon kırıkları gözlemlenebilir. Olgumuz, 16 yaşında erkek sporcu, futbol oynarken topa vurma sonrası sol kalçasında ani ağrı başlayan, topallamaya neden olacak ağrı ve hareket kısıtlılığı nedeniyle acil polikliniğe başvurmuş ve fizik muayenede yumuşak doku travması olarak değerlendirilmiştir. Tarafımıza başvuran hastanın poliklinik kontrollerinde çekilen grafilerinde SİAS avülsiyon kırığı tanısı konuldu. Hastaya non-steroidal anti-enflamatuvar ilaç, tam yük vermeden koltuk değnekleriyle mobilizasyon ve soğuk uygulama ile yaklaşık 4 hafta konservatif tedavi uygulandı. Birinci ay kontrolünde tam ve ağrısız eklem hareket açıklığı olduğu ve palpasyonda ağrı olmadığı saptandı. SİAS avülsiyon kırıkları çoğunlukla konservatif olarak tedavi edilse de iyi fizik muayene yapılmadığında yumuşak doku travması ile karışabilmekte ve özellikle deplasman miktarı fazla olan kırıklar klinik sorunlara sebep olabilmektedir.

Anahtar Sözcülkler: Avülsiyon kırığı, pelvis, apofiz, spina iliaka anterior superior

Address for Correspondence: Mehmet Anıl PULATKAN, Bezmiâlem Vakıf University Faculty of Medicine, Department of Orthopedics and Traumatology, İstanbul, Turkey

E-mail: anilpulatkan@gmail.com ORCID ID: orcid.org/0000-0003-0083-901X 


\section{Introduction}

Spina iliaca anterior superior (SIAS) avulsion fractures are rare and often affect young athletes with non-ossified cartilaginous growth plates during the adolescent period. In this age group, the anterior and posterior edges of the pelvis have lower trabecular density and the growth plates are more susceptible to trauma due to the relative strengthening of the musculotendinous junction with hormonal status (1).

Diagnosis can be made with good anamnesis, physical examination and X-ray. However, these injuries can often be confused with soft tissue trauma. This can lead to improper treatments and a delay in returning to the sport. Although conservative treatments involving rest, non-steroidal anti-inflammatory drugs (NSAIDs), mobilization with crutches without full weight bearing and cold therapy are sufficient, surgical treatment is rarely required (2).

\section{Case Report}

An amateur, male, 16-year-old football player with $178 \mathrm{~cm}$ tall, $70 \mathrm{~kg}$ weight and no known additional disease felt a sudden and sharp pain in the left hip after kicking the ball while he was playing football on the field. He could not continue playing and was admitted to the emergency orthopedics outpatient clinic. The patient was assessed as soft tissue trauma during physical examination and the patient was offered outpatient control. The patient was admitted in the outpatient clinic with complaints of pain in the left hip and difficulty walking. The patient's physical examination revealed painful left hip joint movements, painful limping when walking, and sensitivity on the iliac wing, especially on the left SIAS. The patient was in the $4^{\text {th }}$ stage according to the Tanner's classification.

An avulsion fracture of the left SIAS apophysis with minimal displacement was detected in the X-ray of the patient (Figure 1). The degree of skeletal maturation was stage 3 according to the Risser's classification. Magnetic resonance imaging showed avulsion fracture in the left SIAS apophysis, and no additional soft tissue trauma was detected (Figure 2).

When the patient's examinations were evaluated, the displacement of approximately $3 \mathrm{~mm}$ was found to be suitable for conservative treatment. During the acute period, NSAIDs, cold application and mobilization with crutches without full weight bearing after the first 3 days of bed rest were recommended. The firstmonth control examination showed that the left hip joint range of motion was complete and the left SIAS was painless with palpation. The control X-ray showed that the apophysis of SIAS fully healed (Figure 3).

\section{Discussion}

Apophyses are specialized ossification centers that enable the transverse growth of bones and respond to tensile strengths. Sticking places of the major muscle groups and the tendons are located on the apophyses. These regions are the weakest regions of the musculoskeletal junction in the adolescent age group, and trauma mechanisms that cause muscle injury in adults result in

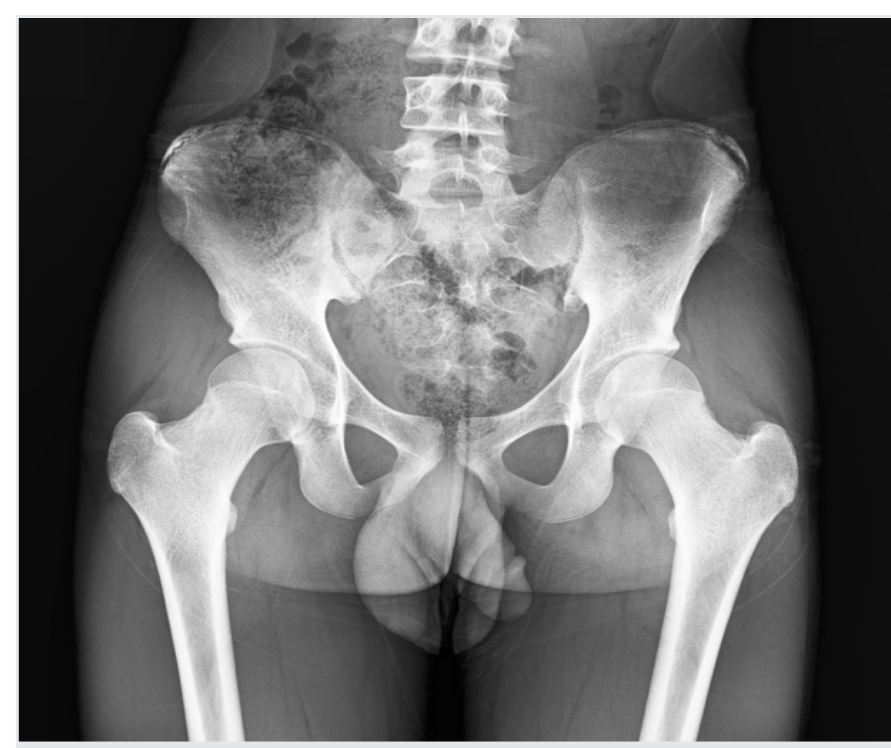

Figure 1. Pelvis AP X-ray image of the patient in his initial arrival. Avulsion fracture is observed in the apophysis of the left SIAS

SIAS: Spina iliaca anterior superior
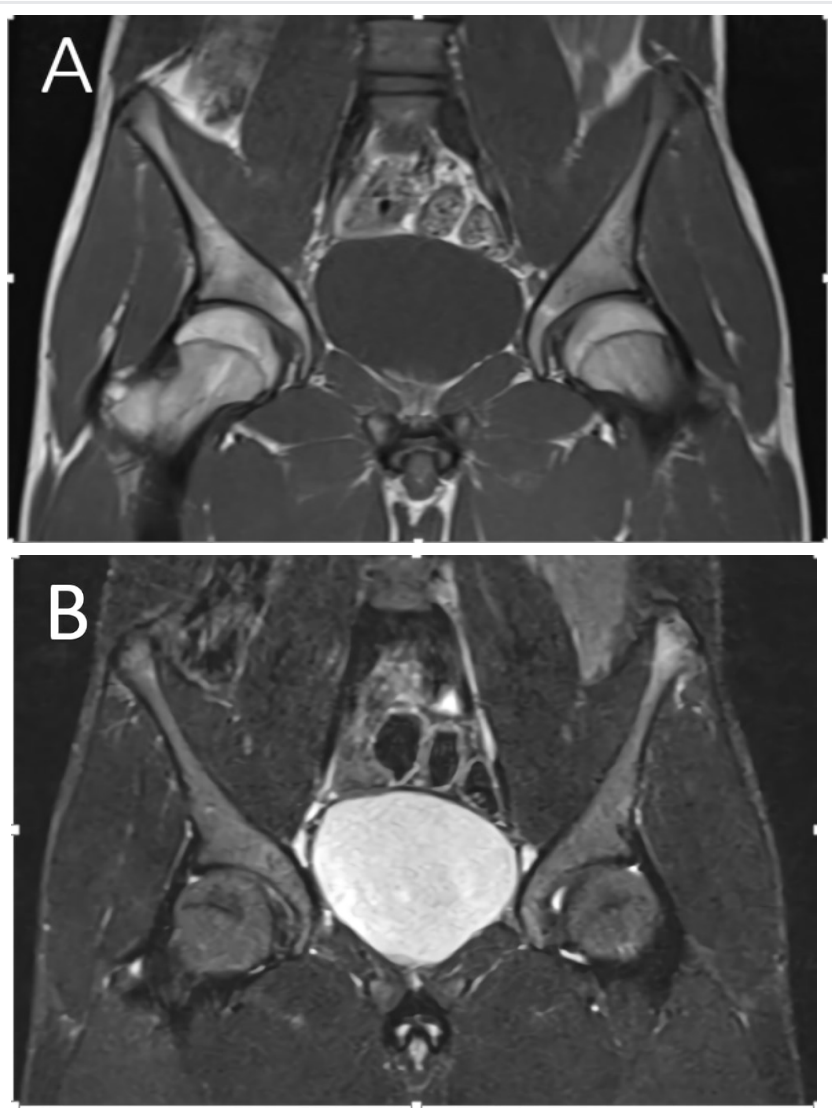

Figure 2. A) Pelvis MRI T1 sequence of the patient in his initial arrival. The fracture line evident on the left SIAS is seen as hypointense B) In pelvic MRI T2 sequence, the edematous region on the left SIAS is seen as hyperintense

SIAS: Spina iliaca anterior superior, MRI: Magnetic resonance imaging 
apophysial cartilaginous avulsion damage in this age group (3). Characteristics including age of 16 and Tanner Stage 4 in our patient were in accordance with the literature.

Pelvic avulsion fractures are among the hardest to diagnose because they are rare. In addition, in recent years, more young people engaged in professional sports have increased the frequency of these fractures relatively. SIAS avulsion fractures account for $15-19 \%$ of rare pelvic avulsion injuries (4). Avulsion fractures of this region are caused by severe contractions of the muscles that hold here, especially during kicking the ball in football players or during the initial phase of running in tennis players (Figure 4). Our patient also suffered an injury while kicking the ball while playing football.

Pelvic avulsion fractures are rare and often confused with muscle spasm or soft tissue trauma. It has been reported in the literature that these fractures can even be mixed with tumor in later times (4). Increased pain with activity, edema and tenderness on the bone during clinical examination should bring avulsion fractures to mind (5). Misdiagnosing these fractures in professional

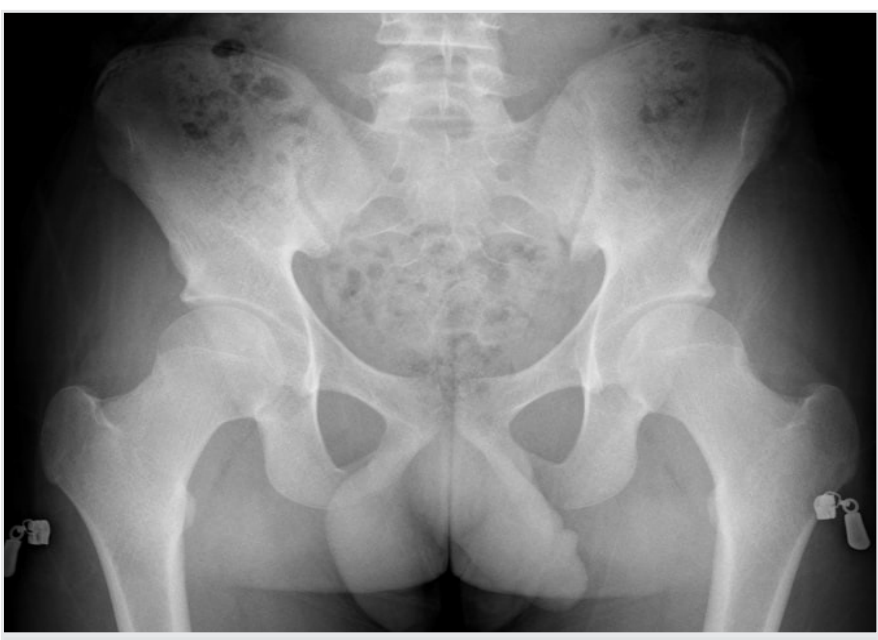

Figure 3. Pelvis AP X-ray in the first month. The left SIAS avulsion fracture appears to heal

SIAS: Spina iliaca anterior superior

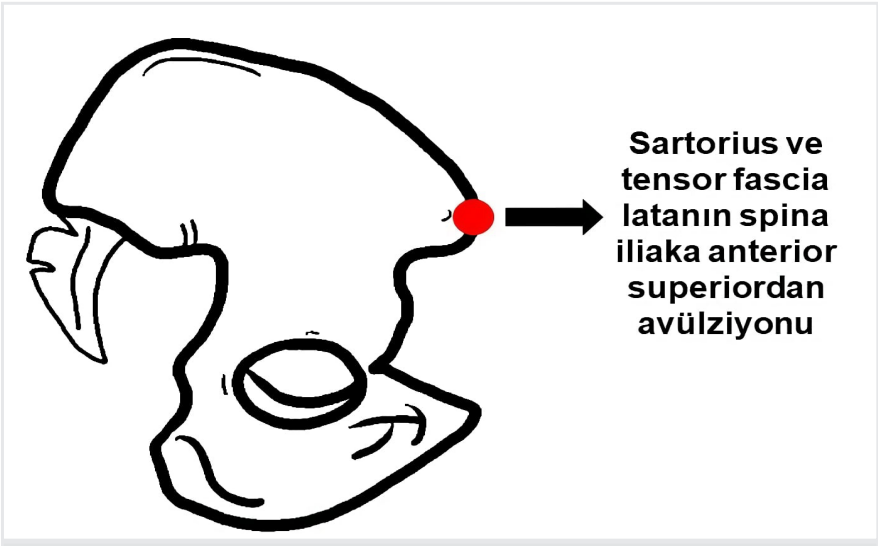

Figure 4. Schematic view of SIAS avulsion fractures.

SIAS: Spina iliaca anterior superior athletes who want to return to the sport early can cause chronic unknown hip pain and make this pain last longer.

Surgical or conservative treatment methods may be preferred in SIAS avulsion fractures. Although the long-term results of these two methods are similar, conservative treatment comes to the fore (6). After 3 days of bed rest, satisfactory results can be obtained with mobilization with crutches and conservative treatment with NSAIDs. The most common complications of conservative treatment are heterotopic ossification and pseudoarthrosis. Surgical treatment is preferred in cases where the fracture displacement is more than $1.5-2 \mathrm{~cm}$ and the separated part is larger (6-8). Although surgical treatment has the advantage of early return to sport, especially in athletes, the need for general anesthesia and the possibility of development of mareljia paraesthetica are among the disadvantages (7). In our patient, pain-free recovery was observed in a month with conservative treatment and sportive activities were started. The clinical outcome of our patient is similar with the literature showing that conservative treatment is sufficient for pelvis avulsion fractures with minimal displacement in athletes.

Since SIAS avulsion fractures can often be confused with soft tissue trauma, diagnosis is not always possible. Proper recognition and treatment of these injuries are important for preventing morbidity such as osteonecrosis and lack of bone repair (9).

\section{Ethics}

Informed Consent: A consent form was completed by all participants.

Peer-review: İnternally peer-reviewed.

\section{Authorship Contributions}

Concept: M.A.P., C.B.D., M.U., İ.T., Design: M.A.P., C.B.D., M.U., İ.T., Data Collection or Processing: M.A.P., C.B.D., M.U., İ.T., Analysis or Interpretation: M.A.P., C.B.D., M.U., İ.T., Literature Search: M.A.P., C.B.D., M.U., İ.T., Writing: M.A.P., C.B.D., M.U., İ.T.

Conflict of Interest: No conflict of interest was declared by the authors.

Financial Disclosure: The authors declared that this study received no financial support.

\section{References}

1. White KK, Williams SK, Mubarak SJ. Definition of two types of anterior superior iliac spine avulsion fractures. J Pediatr Orthop 2002;22:578-82.

2. Schiller J, Defroda S, Blood T. Lower Extremity Avulsion Fractures in the Pediatric and Adolescent Athlete. J Am Acad Orthop Surg 2017;25:251-9.

3. Beck T, Messmer P, Regazzoni P. Unilateral apophyseal fracture of the superior anterior iliac crest--a case report. Swiss Surgery 2003;9:31-4.

4. Dhinsa BS, Jalgaonkar A, Mann B, Butt S, Pollock R. Avulsion fracture of the anterior superior iliac spine: misdiagnosis of a bone tumour. J Orthop Traumatol 2011;12:173-6. 
5. Anduaga I, Seijas R, Pérez-Bellmunt A, Casasayas O, Alvarez P. Anterior Iliac Spine Avulsion Fracture Treatment Options in Young Athletes. J Invest Surg 2018:1-5.

6. Kautzner J, Trc T, Havlas V. Comparison of conservative against surgical treatment of anterior-superior iliac spine avulsion fractures in children and adolescents. Int Orthop 2014;38:1495-8.

7. Pogliacomi F, Calderazzi F, Paterlini M, Pompili M, Ceccarelli F. Anterior iliac spines fractures in the adolescent athletes: surgical or conservative treatment? Medicina Dello Sport 2013;66:231-40.
8. Eberbach H, Hohloch L, Feucht MJ, Konstantinidis L, Südkamp NP, Zwingmann J. Operative versus conservative treatment of apophyseal avulsion fractures of the pelvis in the adolescents: a systematical review with meta-analysis of clinical outcome and return to sports. BMC Musculoskelet Disorders 2017;18:162.

9. Bendeddouche I, Jean-Luc BB, Poiraudeau S, Nys A. Anterior superior iliac spine avulsion in a young soccer player. Ann Phys Rehabil Med 2010;53:584-90. 